\title{
THE ROLE OF UI GREENMETRIC AS A GLOBAL SUSTAINABLE RANKING FOR HIGHER EDUCATION INSTITUTIONS
}

\author{
Nyoman Suwartha ${ }^{1 *}$, Mohammed Ali Berawi ${ }^{1}$ \\ ${ }^{1}$ Faculty of Engineering, Universitas Indonesia, Kampus UI Depok, Depok 16424, Indonesia
}

This note is presented as a continuance of the discussion in the previous edition that focused on how higher education institutions (HEIs) contribute to creating sustainable universities and sustainable futures.

A university is an institution of higher education and research that awards academic degrees in various disciplines. Generally, universities provide undergraduate and postgraduate education to large numbers of students and employ academic and non-academic staffs on a campus with many buildings. Hence, universities can be considered "small cities" (Alshuwaikhat \& Abubakar, 2008), and their numerous daily activities include teaching, researching, and community engagement. Universities also contribute greenhouse gas emissions due to the various people and goods being transported to and from the campus. Universities have different types, functions, sizes, complexities, energy needs, electricity consumption, waste generation, water and materials consumption, public transportation, and education activities; thus, they have significant impacts on the environment. Therefore, over the past two decades, there have been increased discussions regarding the need to consider sustainability in academic institutions.

Many universities in developed countries have been aware of this environmental issue and have taken the lead in initiating and implementing policies for green and sustainable campuses. For example, the US and the UK have had the greatest number of universities actively involved in all aspects of sustainability (Puertas \& Marti, 2019). Several Irish Universities established their policies on sustainability by referring to Education for Sustainable Development (ESD), a document produced by the Irish government that explicitly targets a National Strategy on Education for Sustainable Development in Ireland 2014-2020 (Shawe et al., 2019). Numerous local and global associations have strongly committed to addressing sustainability issues, including the Global Universities Partnership on Environment for Sustainability (GUPES), Sustainable Development Solutions Network (SDSN), International Sustainable Campus Network (ISCN), Association for the Advancement of Sustainability in Higher Education (AASHE), Sustainability University Network (SUN) Thailand, and the Campus Sustainability Network in Japan (CAS-Net Japan). Furthermore, the United Nations Development Programme's 17 Sustainable Development Goals (UNDP 17 SDGs) included HEIs in achieving its SDG targets by 2030, encouraging many more universities to become aware of the need to implement sustainability efforts.

To appreciate and acknowledge universities who have made strong commitments to sustainable efforts, the UI GreenMetric World University Rankings were developed in 2010 as a tool to support developing green universities (Suwartha \& Riri, 2013). The rankings evaluate universities according to six categories: 1) university landscape (setting and infrastructure), 2) electricity consumption (energy and climate change), 3) waste management, 4) water preservation, 5) green transportation for public, and 6) education and research related to 
sustainability. Many of the UNDP 17 SDGs are relevant to these six categories, such as goals 9 and 11 for the setting and infrastructure category; goals 7, 12, and 13 for the energy and climate change category; goals 3, 12, and 14 for the waste management category, goal 6 for the water preservation category; goals 13 and 15 for the green transportation category; and goal 4 for the education and research category.

In 2018, 719 universities from 81 countries participated in the rankings and significantly changed their attitudes toward the sustainability challenges within their own contexts. With so many participants on a global scale, the UI GreenMetric World University Rankings Network (UIGWURN) was established in 2017 to be a platform for sharing best practices and for encouraging more universities to prioritize sustainability agendas. Currently, there are 29 country-based coordinators for the UIGWURN. The network has three main thematic priority activities: (1) Shaping Global Higher Education and Research in Sustainability, (2) Creating Global Sustainability Leaders, and (3) Partnering on Solutions to Sustainability Challenges.

The significant impact of the UI GreenMetric ranking is shown in the increasing number of participants covering regions of North America, South America, Europe, Africa, Asia, and Australia and Oceania. Many participating universities express through their websites sincere gratitude and pride that their continuous sustainability efforts have been acknowledged by being listed in the rankings. The International Ranking Expert Group (IREG) has also shown appreciation for the UI GreenMetric ranking as a global sustainable ranking for universities. Though several authors gave critically analyzed and provided positive feedback regarding green rankings, including the UI GreenMetric (i.e., Ragazzi \& Ghidini, 2017), some authors have proposed a composite indicator using data envelopment analysis (DEA) and the UI GreenMetric that has become known as the DEA-GreenMetric ranking (Puertas \& Marti, 2019).

Therefore, based on the above findings, the UI GreenMetric has been acknowledged globally as the only one sustainability ranking that is simple and accessible and that serves as a benchmark and guide, particularly for helping universities in developing countries create sustainable universities and sustainable futures.

\section{Nurturing Research and Technology Development}

To hasten development in all research areas, various technology improvements through alternative designs, methods, modeling, experiments, and observations are urgently required. Thus, this edition presents 20 papers dedicated to promoting research in engineering and environmental studies that directly and indirectly contributes to sustainable development goals.

The first paper, written by M.M. Julian, A. Brenning, S. Kralisch, and M. Fink, presents the hydrological implications of the spatial plan 2029 and climate change. The authors argue that the hydrological model can explore the impacts of land-use change and climate change, providing useful information for urban planning, environmental decision making, and water resources management.

The next paper, written by A.T. Juniati, D. Sutjiningsih, H. Soeryantono, and E. Kusratmoko, analyzes water availability estimation using the modified Soil Conservation Service Curve Number (SCS-CN) model. The authors argue that from an accurate estimation, water availability can still meet the water demand for current needs; however, there will be a shortage in the next 20 or 30 years.

The third paper, written by S.S.G. Prasad and P.V.V. Satyanarayana, examines the performance of encased silica-manganese slag stone columns in soft marine clay. The authors argue that the soil's engineering behavior was improved by introducing silica-manganese slag, rather than conventional stone columns, and encasement length. 
The fourth paper, written by K.S. Vali and B. Murugan, investigates the impact of nano $\mathrm{SiO}_{2}$ particles on the physical and mechanical properties of cold-bonded artificial lightweight aggregates by the pelletization process. The authors argue that the results could be extremely useful in the enhancement of both the physical and mechanical properties of lightweight aggregates.

The fifth paper, written by P. Sukapto, J.R. Octavia, P.A.D. Pundarikasutra, P.K. Ariningsih, and S. Susanto, evaluates occupational health and safety in the home-based footwear industry. The authors recommend that workshops must improve their working environment, work facilities, and safety climate, as well as the employees' participatory ergonomics.

The sixth paper, written by I.Z. Sutalaksana, S.Z.Z. Zakiyah, and A. Widyanti, examines the link between risk behavior and accident rates in a military tools manufacturer. The authors argue that occupational safety can be achieved through individual approaches based on basic human values and risk perception.

The seventh paper, written by L. Driouach, K. Zarbane, and Z. Beidouri, reviews the use of lean manufacturing in small and medium-sized enterprises. The authors argue that the proposed alternative model can be used to implement lean manufacturing for the specific context of very small businesses (VSBs).

The eighth paper, written by M. Imanullah, E.M. Yuniarno, and A.G. Sooai, proposes a lowcost system for capturing motion using a stereo webcam and some daily house grade tools that have been specifically designed for theatre. The authors argue that the proposed system achieves high accuracy and is cost efficient.

The ninth paper, written by T.M. Amine and D. Ali, proposes a method for building lowdensity-parity-check (LDPC) codes. The authors argue that the proposed codes ensure simple encoding and reduce the stored memory of the matrix $\mathrm{H}$, in which this matrix can be easily built compared to other codes used in channel coding.

The tenth paper, written by A. Khumaeni, H. Sutanto, and W.S. Budi, examines the use of an $\mathrm{Nd}$ :YAG laser operated at a low energy of $30 \mathrm{~mJ}$ to produce gold nanoparticles. The authors argue that the gold nanoparticles with a narrow size distribution and high purity can be successfully produced using the PLA technique.

The eleventh paper, written by N.R. Yanti, H. Heryani, M.D. Putra, and A. Nugroho, examines the triacetin production from glycerol using heterogeneous catalysts prepared from peat clay. The authors argue that the conversion of glycerol for triacetin production using such alumina and silica catalysts yielded levels of $82.7 \%$ and $87.4 \%$, respectively.

The twelfth paper, written by M. Muslim, M.I. Alhamid, Nasruddin, M. Yulianto, and E. Marzuki, examines the variations in heat source temperatures for an organic rankine cycle power plant to produce electricity. The authors argue that the optimum power estimation measured several electrical power outputs between 1.76 and 2.74 kilowatts.

The thirteenth paper, written by M. Dani, A. Dimyati, Parikin, D.R. Adhika, A.K. Jahja, A. Insani, Syahbuddin, and C.A. Huang, examines the microstructure and deformation of austenitic super alloy after arc plasma sintering. The authors argue that the arc plasma sintering leads to a decrease in the area of the eutectic structure at the inter-dendrites and forms microstrain.

The fourteenth paper, written by J.F. Fatriansyah, M.J.Y. Barmaki, R. Lailani, and M. Chalid, presents a crystallization kinetics study of impact polypropylene copolymer with kenaf as a nucleating agent and reinforcement. The authors argue that better crystal growth dynamics yield improved mechanical strength in the IPC+kenaf system. 
The fifteenth paper, written by B. Priyono, A.Z. Syahrial, M.R. Nugraha, D. Sepala, Faizah, and A. Subhan, examines the performance optimization of micro composites for lithium-ion batteries. The authors argue that the compounds of micro composites were successfully synthesized and obtained a reasonably high surface area and minimum aggregation.

The sixteenth paper, written by A.S. Baskoro, R.P. Kurniawan, and Haikal, evaluates the 2-axis movement of a 5-axis gantry robot for welding applications. The authors argue that the best level of robot accuracy is $0.83 \%$ at a velocity of $2.5 \mathrm{~mm} / \mathrm{s}$, while the repeatability rate produces $96 \mu \mathrm{m}$ and $108 \mu \mathrm{m}$ on the $\mathrm{X}$ and $\mathrm{Y}$ axes.

The seventeenth paper, written by D. Suwandi, R. Aziz, A. Sifa, E. Haris, J. Istiyanto, and Y. Whulanza, examines the application of dry film photoresist on printed circuit board (PCB). The authors argue that a maskless photolithography process was successfully conducted using DLP Projector Infocus IN114A applied to dry film photoresist.

The eighteenth paper, written by M. Malawat, D.A. Sumarsono, J. Istiyanto, F. Dionisius, and G. Prayogo, presents the prediction of dynamic axial crushing on a square tube with eight holes used as a crush initiator. The authors argue that the proposed formulas can be used to predict the average force, peak force, and energy absorption of the dynamic axial crushing.

The nineteenth paper, written by I.A.C. Abar and I.K.A.P. Utama, examines the effect of incline angle of propeller boss cap fins (PBCF) on ship propeller performance. The authors argue that the PBCF convergent hub results in an increased efficiency of around $0.8 \%$, whereas the divergent type decreases efficiency by about $1.0 \%$.

The twentieth and final paper, written by M.Z.M. Alie and S.I. Latumahina, investigates the progressive collapse of the local elements and the ultimate strength of a ro-ro ship. The authors argue that the deformation of the local elements on the deck and bottom parts indicate that stress concentration appeared.

We hope that this edition of IJTech conveys some new insights in how we conduct our research. We are pleased to accept and respond to any comment or enquiry you may have on the direction and content of IJTech, and we invite you to join us in this venture by sending your work for consideration.

With warmest regards from Jakarta,

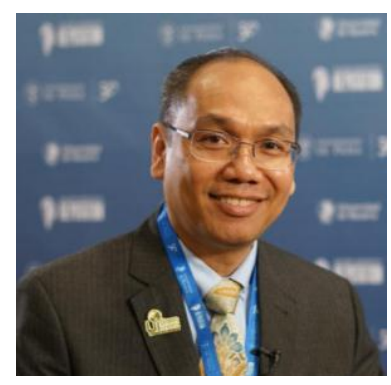

Dr. Nyoman Suwartha Managing Editor

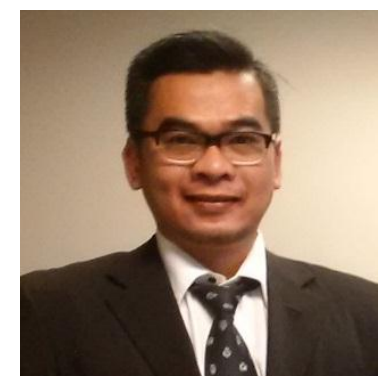

Dr. Mohammed Ali Berawi Editor in Chief 